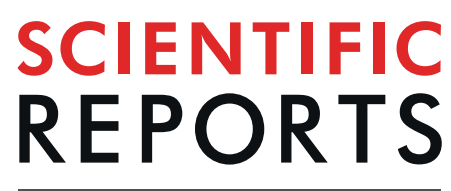

natureresearch

\title{
OPEN The production of L- and D- phenylalanines using engineered phenylalanine ammonia lyases from Petroselinum crispum
}

\begin{abstract}
Souad Diana Tork ${ }^{1,2}$, Emma Zsófia Aletta Nagy ${ }^{1,2}{ }^{2}$ Lilla Cserepes ${ }^{1}$, Diana Monica Bordea ${ }^{1}$, Botond Nagy ${ }^{1}$, Monica loana Toşa ${ }^{1}$, Csaba Paizs ${ }^{1}$ \& László Csaba Bencze $\mathbb{C}^{1 *}$

The biocatalytic synthesis of $L$ - and $D$-phenylalanine analogues of high synthetic value have been developed using as biocatalysts mutant variants of phenylalanine ammonia lyase from Petroselinum crispum (PCPAL), specifically tailored towards mono-substituted phenylalanine and cinnamic acid substrates. The catalytic performance of the engineered PcPAL variants was optimized within the ammonia elimination and ammonia addition reactions, focusing on the effect of substrate concentration, biocatalyst:substrate ratio, reaction buffer and reaction time, on the conversion and enantiomeric excess values. The optimal conditions provided an efficient preparative scale biocatalytic procedure of valuable phenylalanines, such as $(S)$ - $m$-methoxyphenylalanine $(Y=40 \%$, ee $>99 \%)$, (S)-pbromophenylalanine $(Y=82 \%$, ee $>99 \%)$, $(S)$ - $m$-(trifluoromethyl)phenylalanine $(Y=26 \%$, ee $>99 \%)$, $(R)$ - $p$-methylphenylalanine, $(Y=49 \%$, ee $=95 \%)$ and $(R)$ - $m$-(trifluoromethyl)phenylalanine $(Y=34 \%$, ee $=93 \%$ ).
\end{abstract}

Substituted phenylalanines are important chiral building blocks for pharmaceutical industry, their incorporation into small-molecule therapeutic agents, or peptides and proteins, is commonly approached ${ }^{1,2}$. Biocatalytic procedures continuously emerged with the aim to provide green alternatives for the production of these valuable synthons. Phenylalanine ammonia lyases (PALs, EC 4.3.1.24 and PAL/TALs with combined phenylalanine and tyrosine ammonia lyase activities, EC 4.3.1.25) are among the most studied biocatalysts for the production of optically pure Dand L-phenylalanine analogues ${ }^{3-14}$ with PAL-based industrial processes already known, such as the multitone scale production of (S)-2,3-dihydro- $1 H$-indole-2-carboxylic acid by DSM (Netherlands) ${ }^{15}$. The phenylalanine ammonia lyase from Petroselinum crispum (PcPAL) is one of the most intensively employed PALs, that either as whole cell, purified or immobilized biocatalyst, provided a wide range of both $\mathrm{L}$ - and D-phenylalanine analogues ${ }^{16-21}$. Protein engineering of PALs ${ }^{8,9,12,22-25}$, but also of the structurally and mechanistically closely related phenylalanine aminomutases (PAMs, EC 5.4.3.10/11) ${ }^{26-29}$, with mixed $\alpha$ - and $\beta$-regioselectivity ${ }^{30,31}$, provided variants with enhanced activity/selectivity towards several arylalanine derivatives. Recently the mapping of the hydrophobic binding region of PcPAL active site ${ }^{8}$ revealed that its catalytic efficiency towards targeted substrates can be tailored through rational design, considering the position (ortho-, meta- or para-) of substrate's ring-substituent.

Based on these results, within this study we focused on the development of efficient biocatalytic technologies for the production of several valuable L- and D-Phe analogues, using the specifically tailored PcPAL variants $^{8}$ (Fig. 1). The targeted Phe-analogues include L- $p$-bromophenylalanine L-1i, an important intermediate in the production of several biarylalanines ${ }^{12}$ or L- $m$-(trifluoromethyl)phenylalanine $\mathrm{L}-\mathbf{1 k}$, integrated in kinesin KIFC1 inhibitors ${ }^{32}$, with essential role in centrosomal bundling within cancer cells. Similarly, its enantiomer pair $\mathrm{D}-m$-(trifluoromethyl)phenylalanine $\mathrm{D}-\mathbf{1 k}$ is key chiral intermediate for $(R)-\mathrm{PFI}-2^{33}$, a potent inhibitor for SET domain containing lysine methyltransferase 7 (SETD 7) involved in multiple cancer-related signaling pathways, while $\mathrm{D}$ - $p$-methylphenylalanine $\mathrm{D}-\mathbf{1 c}$ is incorporated into Pin1 inhibitors ${ }^{34}$, as well as anti-inflammatory formyl peptide receptor 1 antagonist ${ }^{35}$. Methoxy-substituted phenylalanines, such as L- $p$-methoxyphenylalanine L-1f and L- $m$-methoxyphenylalanine $\mathrm{L}-1 \mathrm{e}$ are also well-known key intermediates for the synthesis of tamsulosin ${ }^{36}$ and HIV protease inhibitors ${ }^{37}$, respectively.

${ }^{1}$ Biocatalysis and Biotransformation Research Center, Faculty of Chemistry and Chemical Engineering, Babeș-Bolyai, University of Cluj-Napoca, Arany János Str. 11, RO-400028, Cluj-Napoca, Romania. ${ }^{2}$ These authors contributed equally: Souad Diana Tork and Emma Zsófia Aletta Nagy. *email: cslbencze@chem.ubbcluj.ro 


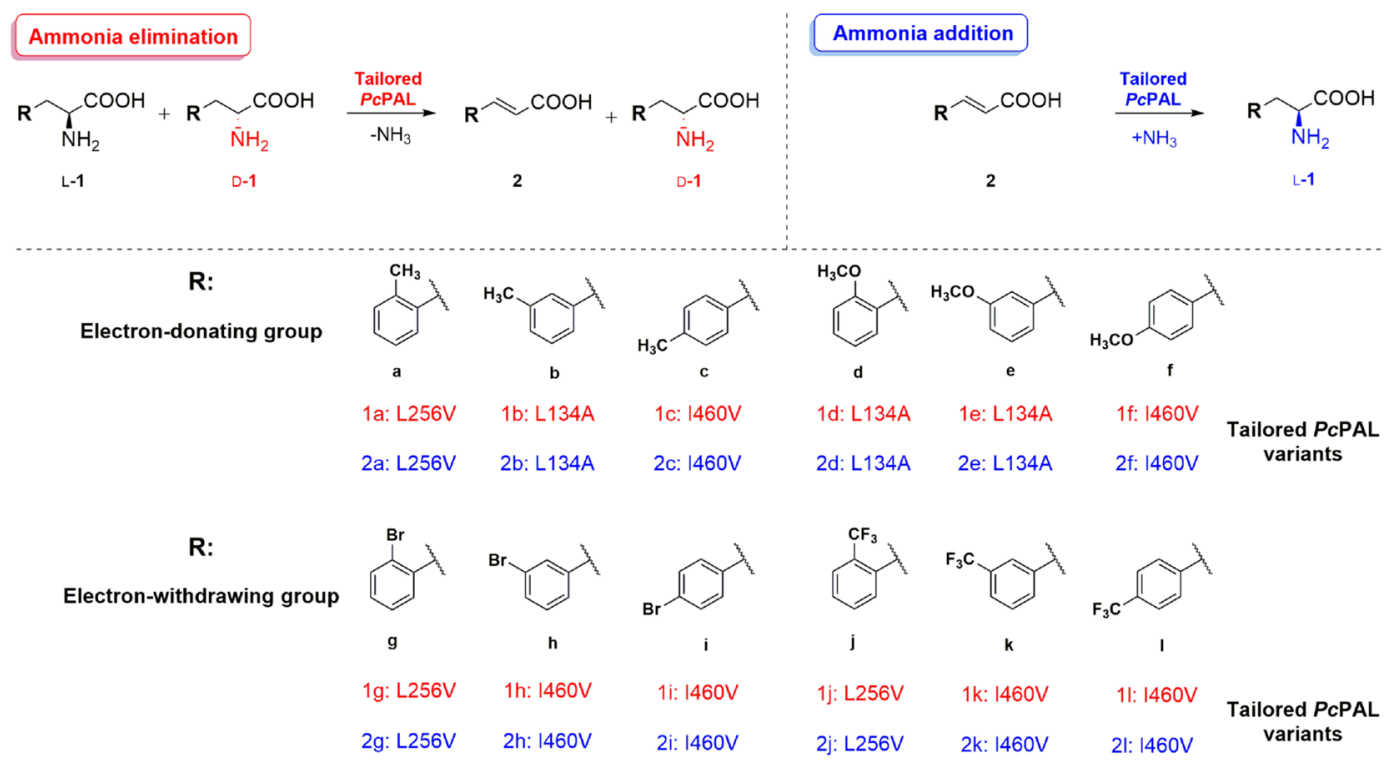

Figure 1. The ammonia addition and ammonia elimination reactions of ring-substituted cinnamic acids and racemic phenylalanines, catalyzed by the corresponding tailored PcPAL variant ${ }^{8}$.

\section{Results and Discussion}

While PcPAL in terms of catalytic efficiency $\left(\mathrm{k}_{\mathrm{cat}}, \mathrm{k}_{\mathrm{cat}} / \mathrm{K}_{\mathrm{M}}\right)$ is among the most efficient PALs both for the natural ammonia elimination and for the reverse ammonia addition reactions ${ }^{10,38}$, its tailored mutant variants, in comparison with the wild-type enzyme, present even superior kinetic parameters within the reactions of the non-natural substrates ${ }^{8}$ (Fig. 1). Accordingly, in order to develop efficient preparative scale PAL-procedures towards phenylalanines of high synthetic interest, we focused on the reaction engineering of both ammonia addition and ammonia elimination reaction routes (Fig. 1), using as biocatalysts the engineered PcPAL variants.

Notable, that the ammonia addition reactions, as asymmetric synthetic procedure present advantageous synthetic potential over the ammonia elimination reactions: $100 \%$ theoretical yield for L-Phe analogues and the use of synthetically accessible, achiral starting materials as compared to the kinetic resolution type ammonia eliminations, that yields the D-phenylalanines in maximal theoretical yield of 50\% from their racemic mixtures. Higher yields of D-phenylalanines can be obtained by coupling the ammonia addition reaction with a stereoselective oxidation catalyzed by L-amino acid deaminases, followed by a chemical non-selective reduction step, within a one-pot procedure ${ }^{39}$.

Optimization of ammonia additions. During the optimizations of ammonia addition reactions, we studied the effect of the reaction medium/ammonia source, biocatalysts:substrate ratio, substrate concentration on the conversion and enantiomeric excess (ee) values, using $p$-methylcinnamic acid $2 \mathrm{c}$ and $p$-(trifluoromethyl) cinnamic acid $\mathbf{2 l}$ as model substrates.

The effect of ammonia source. The effect of the reaction medium, serving both as ammonia source and reaction buffer, was tested at $2 \mathrm{mM} 2 \mathrm{c}$ and $2 \mathrm{l}$ using whole cell PcPAL-biocatalysts in cell densities of $\mathrm{OD}_{600} \sim 1(\sim 6 \mathrm{mg}$ wet cells $/ \mathrm{mL})$ in aqueous solutions of different concentrations of ammonia $\left(2,4,6 \mathrm{M} \mathrm{NH}_{4} \mathrm{OH}\right.$ pH 10 adjusted with $\mathrm{CO}_{2}$ ) or ammonium carbamate $\left(2,4,6 \mathrm{M} \mathrm{NH}_{4}\left[\mathrm{H}_{2} \mathrm{NCO}_{2}\right], \mathrm{pH} 9.6-10\right.$ without adjustment) (Fig. 2a,b). While in previous PAL-mediated biotransformations $2 \mathrm{M}$ and $4 \mathrm{M}$ ammonium carbamate proved to be the optimal ammonia source ${ }^{11,24}$, in our case the highest conversions were achieved using $6 \mathrm{M} \mathrm{NH}_{4} \mathrm{OH}(30.2 \%$ for $2 \mathrm{c}$ and $60.3 \%$ for $\mathbf{2 l}$ after $24 \mathrm{~h}$ ), while using high ammonium carbamate concentrations (4-6 M) significantly lower conversion values $(11.1 \%, 20.6 \%$ for $2 \mathrm{c}$ and $<1 \%, 17.6 \%$ for $2 \mathrm{l}$ after $24 \mathrm{~h}$, respectively) were obtained. In accordance with the fact that ammonium carbamate can provide 2 molecules of ammonia, instead of 1 provided by $\mathrm{NH}_{4} \mathrm{OH}$ and also an overall lower ionic strength, the conversions using $2 \mathrm{M} \mathrm{NH}_{2} \mathrm{CO}_{2} \mathrm{NH}_{4}$ approximated the optimal values registered in $6 \mathrm{M} \mathrm{NH}_{4} \mathrm{OH}$ (Fig. 2a,b), but not exceed them as in previous studies ${ }^{11,24}$. Under lower ammonia and ammonium carbamate content significantly decreased conversion values were obtained, supporting the necessity of high ammonia concentration for the reverse, ammonia addition reactions.

The effect of biocatalyst:substrate ratio. The biocatalyst:substrate ratio was varied, by using different densities of whole cell PcPAL biocatalysts $\left(\mathrm{OD}_{600}\right.$ of $\sim 1,2,4,8$ corresponding to a wet cell concentration of $\sim 6,12,24,48 \mathrm{mg} /$ $\mathrm{mL}$ ) at fixed $2 \mathrm{mM}$ concentration of model substrates $2 \mathrm{c}$ and $\mathbf{2 l}$, monitoring the conversions and ee values of products for the corresponding ammonia addition reactions (Fig. 3a,b). While cell densities of $\mathrm{OD}_{600}$ of $\sim 4,8$ provided the highest conversions, they significantly enhanced the viscosity of the reaction medium, hindering both sample preparation and reaction monitoring by HPLC (appearance of additional, interfering signals). Thus, cell densities of $\mathrm{OD}_{600} \sim 2$, corresponding to biocatalyst: substrate ratio $\left(\mathrm{OD}_{600}: \mathrm{mM}\right)$ of 1 was selected for further experiments, 
a)

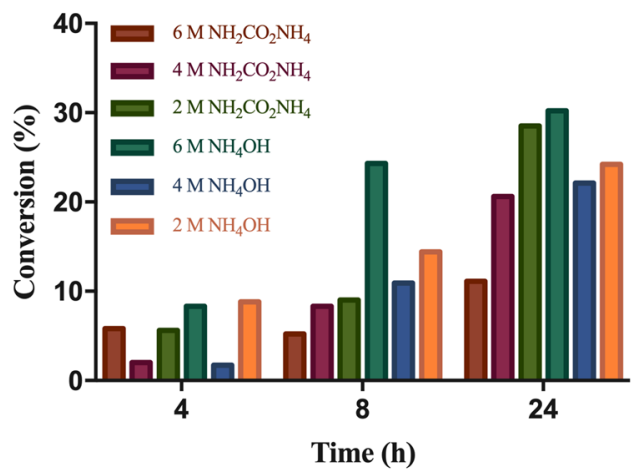

b)

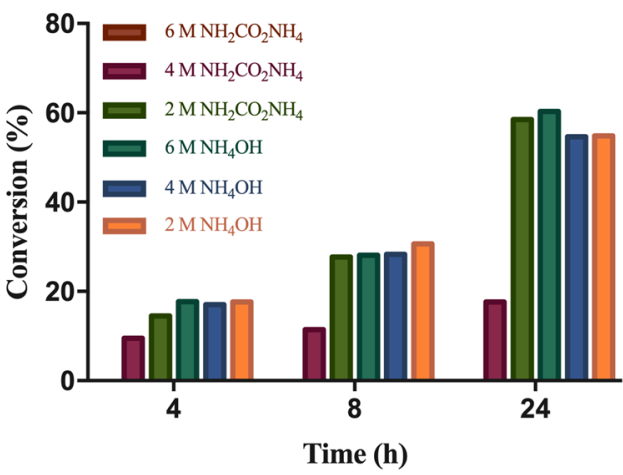

Figure 2. Conversion values of ammonia addition reactions of (a) $p-\mathrm{CH}_{3}$-cinnamic acid (c,b) $p$ - $\mathrm{CF}_{3}$-cinnamic acid 2l, using different ammonia sources. In all points of the reactions the enantiomeric excess (ee) values were $>99 \%$, while in case of using $6 \mathrm{M} \mathrm{NH}_{4}\left[\mathrm{H}_{2} \mathrm{NCO}_{2}\right]$ no conversion of $2 \mathbf{l}$ could be detected.

a)

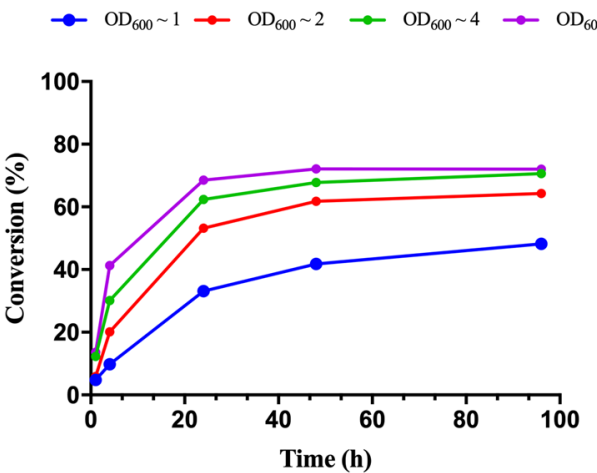

b) $\rightarrow \mathrm{OD}_{600} \sim 1 \rightarrow \mathrm{OD}_{600} \sim 2 \rightarrow \mathrm{OD}_{600} \sim 4 \rightarrow \mathrm{OD}_{600} \sim 8$

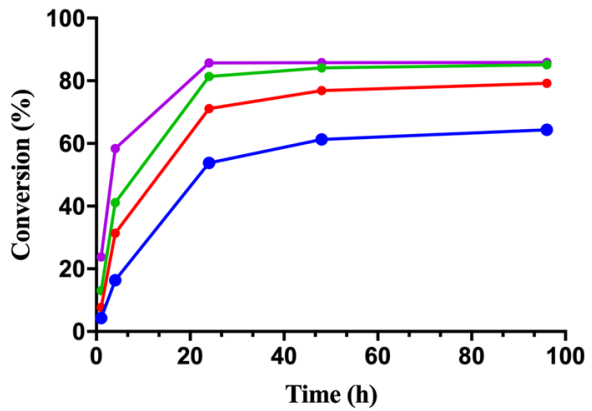

Figure 3. The effect of increased cell densitities of the whole-cell PcPAL biocatalysts upon the conversion values of ammonia addition onto (a) $p$-methylcinnamic acid $2 \mathbf{c}$ and (b) $p$-(trifluoromethyl)cinnamic acid $2 \mathbf{l}$. In all points of the reactions the $e e$ values were $>99 \%$.

as they provided relatively high conversions $(61.8 \%$ for $\mathbf{2 c}$ and $76.9 \%$ for $\mathbf{2 l})$ and moderate medium viscosity for the further optimization steps.

The effect of substrate concentration. The solubilities of model substrates $\mathbf{2} \mathbf{l}$ and $\mathbf{2 c}$ were tested in the reaction buffers providing the highest conversions $\left(6 \mathrm{M} \mathrm{NH}_{4} \mathrm{OH}\right.$ and $2 \mathrm{M}$ ammonium carbamate, Fig. 2a,b). Besides the conversion values (Fig. 2a,b), the solubilities of the model substrates $2 \mathbf{l}$ and $2 \mathrm{c}$ were also higher in $6 \mathrm{M} \mathrm{NH}_{4} \mathrm{OH}$ in comparison with the $2 \mathrm{M}$ ammonium carbamate solution, providing substrate concentrations below $5 \mathrm{mM}$.

Therefore, using the optimal reaction medium $\left(6 \mathrm{M} \mathrm{NH}_{4} \mathrm{OH}\right.$ at $\left.\mathrm{pH} 10\right)$, and maintaining the biocatalysts:substrate concentration ratio $\left(\mathrm{OD}_{600}: \mathrm{mM}\right)$ at the optimal value of 1 , the ammonia additions onto all substrates 2a-1 were performed varying the substrate concentration in the limit of their solubilities (Figs. 4a,b and S2-S11).

In most cases the progression of the conversions slowed down with increasing substrate concentration, leading to longer reaction times at high substrate concentrations.

The ortho-substituted substrates $\mathbf{2 a}, \mathbf{g}, \mathbf{j}$, were transformed with high conversions of $66-91 \%$ after $48 \mathrm{~h}$ reaction time, even substrate concentrations as high as 30-70 mM (Figs. S2, S7, S9). In contrast, the ammonia addition onto $o-\mathrm{OCH}_{3}$-substituted $\mathbf{2 d}$ was seriously affected by the increase of substrate concentrations above $10 \mathrm{mM}$. In this case the stationary conversions decreased from the moderate $\sim 46 \%$ to lower values of $\sim 25 \%$, when using substrate concentrations of 2-10 $\mathrm{mM}$ and $20-70 \mathrm{mM}$, respectively (Fig. S5).

Similar tendency was registered for meta-substituted substrates, where concentrations higher than $2 \mathrm{mM}$ substantially decreased the conversion values (Figs. S3, S8, S10 for $\mathbf{2 b}, \mathbf{h}$ and $\mathbf{k}$ ), except for $m$-methoxycinnamic acid 2e (Fig. 4a), where conversion values maintained at $~ 71 \%$ even at high $50 \mathrm{mM}$ substrate concentration.

In case of para-substituted substrates, substrate concentrations not affecting the final conversions were higher for substrates with electron donating substituents $(30 \mathrm{mM}$ for $\mathbf{2 c}$ and $\mathbf{2 f}-$ Figs. S4, S6) than for substrates with electron withdrawing substituents $(10 \mathrm{mM}$ and $2 \mathrm{mM}$ for $\mathbf{2 i}$ and $\mathbf{2 l}$, respectively - Figs. $4 \mathrm{~b}, \mathrm{~S} 11)$.

In case of $m-\mathrm{CH}_{3}$-cinnamic acid $\mathbf{2 b}, o-\mathrm{OCH}_{3}$-cinnamic acid $\mathbf{2 d}, p-\mathrm{CF}_{3}$-cinnamic acid $\mathbf{2 l}$ the ammonia additions stopped at low conversions (15-42\%) even in case of low substrate concentrations (2-10 mM, Figs. S3, S5, 
a) $2 \mathrm{mM}$ $10 \mathrm{mM}$ $50 \mathrm{mM}$

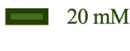
$70 \mathrm{mM}$

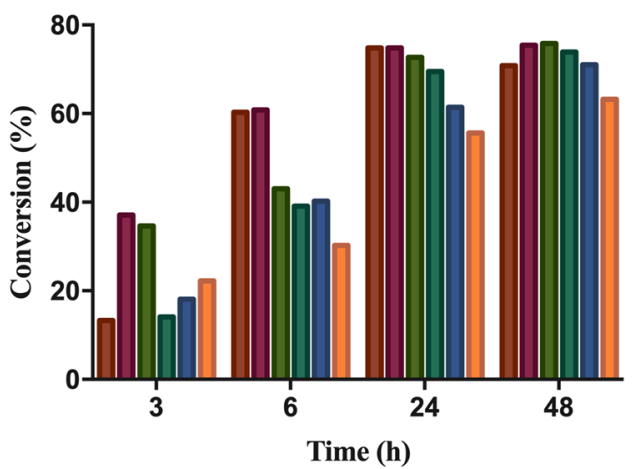

b)

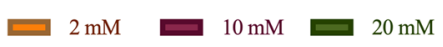

Figure 4. The effect of substrate concentration on the conversion values of ammonia additions onto (a) $\mathrm{m}$ $\mathrm{OCH}_{3}$-cinnamic acid 2e using L134A PcPAL (b) $p$-Br-cinnamic acid $2 \mathbf{i}$ using I460V PcPAL. In all points of the reactions the enantiomeric excess (ee) values were above $99 \%$.

\begin{tabular}{|l|l|l|l|l|l|l|}
\hline Substrate & Substituent & PcPAL & {$[\mathbf{S}](\mathbf{m M})$} & Time (h) & $\mathbf{c}(\%)$ & ee $_{\mathbf{L}}(\%)$ \\
\hline $2 \mathrm{a}$ & $\mathrm{o}-\mathrm{CH}_{3}$ & L256V & 70 & 24 & 91.5 & $>99$ \\
\hline $2 \mathrm{~b}$ & $\mathrm{~m}-\mathrm{CH}_{3}$ & L134A & 2 & 48 & 26.4 & $>99$ \\
\hline $2 \mathrm{c}$ & $\mathrm{p}-\mathrm{CH}_{3}$ & I460V & 30 & 48 & 59.9 & $>99$ \\
\hline $2 \mathrm{~d}^{*}$ & $\mathrm{o}-\mathrm{OCH}_{3}$ & L134A & 10 & 24 & 42.5 & $>99$ \\
\hline $2 \mathrm{e}^{*}$ & $\mathrm{~m}-\mathrm{OCH}_{3}$ & L134A & 50 & 48 & 71.0 & $>99$ \\
\hline $2 \mathrm{f}^{*}$ & $\mathrm{p}-\mathrm{OCH}_{3}$ & I460V & 30 & 48 & 19.1 & $>99$ \\
\hline $2 \mathrm{~g}^{*}$ & $\mathrm{o}-\mathrm{Br}$ & $\mathrm{L} 256 \mathrm{~V}$ & 70 & 24 & 81.6 & $>99$ \\
\hline $2 \mathrm{~h} *$ & $\mathrm{~m}-\mathrm{Br}$ & I460V & 5 & 24 & 70.1 & 98.3 \\
\hline $2 \mathrm{i}^{*}$ & $\mathrm{p}-\mathrm{Br}$ & I460V & 10 & 24 & 61.6 & $>99$ \\
\hline $2 \mathrm{j}^{*}$ & $\mathrm{o}-\mathrm{CF}_{3}$ & L256V & 20 & 24 & 73.0 & $>99$ \\
\hline $2 \mathrm{k}$ & $\mathrm{m}-\mathrm{CF}_{3}$ & I460V & 2 & 24 & 77.5 & $>99$ \\
\hline $2 \mathrm{l}^{*}$ & $\mathrm{p}-\mathrm{CF}_{3}$ & I460V & 2 & 48 & 42.2 & $>99$ \\
\hline
\end{tabular}

Table 1. Conversion and enantiomeric excess (ee) values of L-1a-1 obtained in the ammonia addition reactions performed under optimal conditions $s^{\mathrm{a}} .{ }^{\mathrm{a}}$ Reaction conditions: assays were performed in $1.5 \mathrm{~mL}$ polypropylene tubes at $30^{\circ} \mathrm{C}, 200 \mathrm{rpm}$ for $16 \mathrm{~h}$, in $500 \mu \mathrm{L}$ reaction volume, using $2-70 \mathrm{mM}$ substrate concentration, ratio of cell density $\left(\mathrm{OD}_{600}\right)$ /substrate concentration $(\mathrm{mM})$ of 1.0 and $6 \mathrm{M} \mathrm{NH}_{4} \mathrm{OH}$ at $\mathrm{pH} 10$ (adjusted with $\mathrm{CO}_{2}$ ) as reaction medium. *The optimal substrate concentrations were selected considering the shortest reaction time leading to highest $e e$ and conversion values.

S11), suggesting the occurrence of substrate inhibition. This was further supported by the inhibitory effect of increasing substrate concentration on the reaction velocities of the ammonia addition reaction of $2 \mathbf{l}$, determined through the UV-based PAL-activity assay, using purified I460V PcPAL as biocatalyst (Fig. S22).

Using the optimal conditions specific for each substrate, the ammonia additions onto all substrates 2a-1 were performed, with the aim to determine the final, stationary conversions and ee values. Most of the reactions proceeded with high or moderate conversions and provided the $\mathrm{L}$-Phe derivatives $\mathrm{L}-\mathbf{1} \mathbf{- 1}-\mathbf{l}$ in excellent ees (Table 1). As exception, the ammonia addition reactions of $\mathbf{2 b}$ and $\mathbf{2} \mathbf{f}$ stopped at low stationary conversions of $26.4 \%$ and $19.1 \%$, respectively (Table 1), which were maintained even after adding fresh batch of PcPAL-whole cells (preceded by the removal of the initial whole cell-batch by centrifugation). The significantly decreased conversions and reaction velocities of the ammonia addition onto $\mathbf{2} \mathbf{b}$ and $\mathbf{2} \mathbf{f}$, performed in presence of increasing concentrations of $\mathbf{1 b}$ and 1f, respectively, supports the occurrence of product inhibition in these cases (Figs. S24-S26).

In terms of comparison with similar PAL mediated procedures, the optimized biotransformations provide superior conversions and enantiomeric excess values for the ammonia additions onto $o$-, $m$-, $p$ - $\mathrm{OCH}_{3}$-cinnamic acids to those reported for the wild-type $\mathrm{PcPAL}^{8}$ or PAL from Anabaena variabilis (AvPAL) ${ }^{10,40}$, and approximates, in case of $o-\mathrm{OCH}_{3}$-cinnamic acid even surpasses, the conversions obtained with the improved variants of PAL from Planctomyces brasiliensis (PbPAL), reported for its remarkable high activity towards cinnamic acids bearing electron donor ring substituents ${ }^{25,40}$. The high enantiomeric excess values of the trifluoromethyl-substituted L-phenylalanines L-1 j-k obtained with moderate to high conversions (Table 1) exceed the ee values previously obtained through wild-type AvPAL, PcPAL or PAL from Rhodotorula glutinis $(R g P A L)^{10,39}$. In case of $p$-Br-substituted substrate $\mathbf{2 i}$, the obtained results are comparable with the procedures based on improved 
a)

$$
\begin{aligned}
& \rightarrow \text { Tris pH } 8.8 \rightarrow 0.1 \mathrm{MNH}_{3} \rightarrow \mathrm{Na}_{2} \mathrm{CO}_{3} / \mathrm{NaHCO}_{3} \\
& \rightarrow \text { Borax } \rightarrow \text { Phosphate } \rightarrow \mathrm{CH}_{3} \mathrm{COONH}_{4}
\end{aligned}
$$

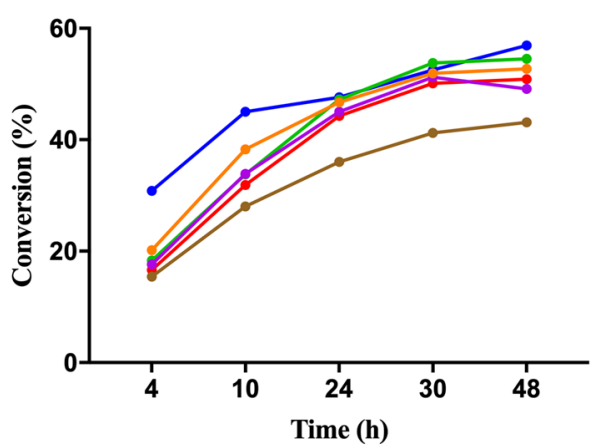

b)

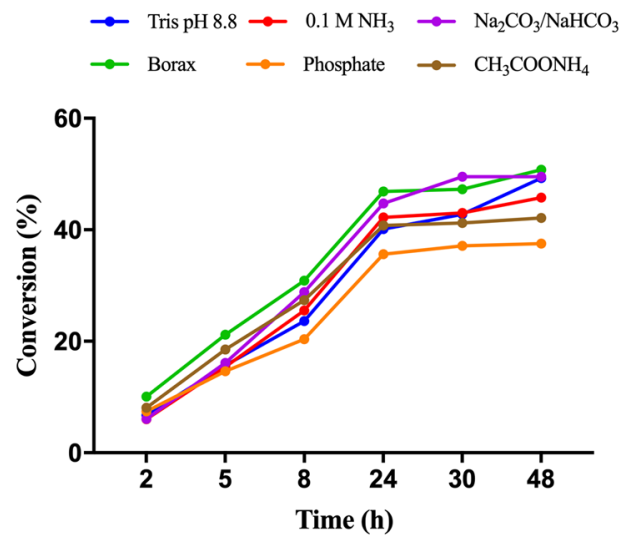

Figure 5. Conversion values of ammonia elimination reactions performed in different buffers, using I460V $\mathrm{PcPAL}$ as biocatalyst and (a) rac- $m-\mathrm{CF}_{3}$-phenylalanine $\mathrm{rac}-\mathbf{1 k}$ or (b) $\mathrm{rac}-\mathrm{p}-\mathrm{CH}_{3}$-phenylalanine $\mathrm{rac}$ - $\mathbf{1 c}$ as substrate. In all cases the experimentally determined ee values of the nonreacted $\mathrm{D}-\mathbf{1} \mathbf{k}, \mathbf{1} \mathbf{c}$ were in accordance with the theoretical ee values, calculated from the corresponding conversion values (data not shown).

$A v$ PAL variants ${ }^{12}$, but are surpassed by the conversions obtained by the $31 \mathrm{E}$ variant of Rhodotorula graminis PAL (RgrPAL $)^{24}$. While AvPAL-mediated ammonia additions onto methyl-substituted cinnamic acids were also reported ${ }^{25}$, the optimized PcPAL procedures provide superior conversions (in case of $o$ - and $p$-methylcinnamic acids) and enantiomeric excess values (for $o$ - and $m$-methylphenylalanine) (Table 1 ).

Ammonia elimination optimizations. For the optimization process of the kinetic resolution-type ammonia eliminations from racemic phenylalanine analogues, $\mathrm{rac}-\mathbf{1} \mathbf{c}$ and $\mathrm{rac}$-1 $\mathbf{k}$ were chosen as model substrates. Besides aiming to achieve conversion approximating the optimal $50 \%$ of a highly selective kinetic resolution, we monitored the enantioselectivity of the resolution process, by the correlation of the experimentally determined $e e$ values of the unreacted $\mathrm{D}$-enantiomer with the theoretical ee values, calculated from the obtained conversions, considering a fully enantioselective resolution process. Since during a kinetic resolution of high enantioselectivity (with E»200), only the ammonia elimination from the L-Phe derivative occurs, the ee of the unreacted $\mathrm{D}$-enantiomer increases upon the progress of the reaction and reaches the optimal value of $100 \%$ at conversion values approximating $50 \%$.

The effect of reaction medium. The optimal $\mathrm{pH}$ of PALs generally ranges from 8.2-9.5 $5^{41-43}$. In accordance with these data, using whole cell PcPAL biocatalyst in Tris-buffers of different $\mathrm{pH}$ values as reaction medium, the highest conversions were obtained at $\mathrm{pH}$ values $>8.8$. (Fig. S1). Further, the influence of various buffer systems, such as Tris (20 mM Tris. $\mathrm{HCl}, 120 \mathrm{mM} \mathrm{NaCl}, \mathrm{pH} 8.8), \mathrm{NH}_{3}$-buffer $\left(0.1 \mathrm{M} \mathrm{NH}_{4} \mathrm{OH}, \mathrm{pH}\right.$ 9.5, adjusted with $\left.\mathrm{CO}_{2}\right)$, borax $\left(0.1 \mathrm{M} \mathrm{Na}_{2}\left[\mathrm{~B}_{4} \mathrm{O}_{5}(\mathrm{OH})_{4}\right], \mathrm{pH} 9.5\right)$, ammonium acetate buffer $\left(0.1 \mathrm{M} \mathrm{CH}_{3} \mathrm{COONH}_{4}, \mathrm{pH} 9.5\right.$,) sodium carbonate $\left(0.1 \mathrm{M} \mathrm{Na}_{2} \mathrm{CO}_{3}, \mathrm{pH} 9.0\right)$ and phosphate-buffer $\left(0.1 \mathrm{M} \mathrm{Na}_{2} \mathrm{HPO}_{4}-\mathrm{NaH}_{2} \mathrm{PO}_{4}, \mathrm{pH} 8.8\right)$, on the conversion and ee values were studied using a fixed substrate concentration of $2 \mathrm{mM}$ from model substrates, $\mathrm{rac}-\mathbf{1} \mathbf{c}$ and $\mathrm{rac}-\mathbf{1 k}$, and a 1:2 whole-cell PcPAL biocatalyst:substrate ratio $\left(\mathrm{OD}_{600}: \mathrm{mM}\right)$. The $\mathrm{pH}$ values of all tested buffers position within the found optimal $\mathrm{pH}$ domain (Fig. S1).

In case of $\mathrm{rac}$ - $\mathrm{m}$-(trifluoromethyl)phenylalanine ( $\mathrm{rac}$-1k), the conversions reached $50 \%$ in all cases after $30 \mathrm{~h}$ reaction time with the exception of ammonium acetate buffer, where the maximum conversion was not reached even after $48 \mathrm{~h}(43.1 \%)$. The highest conversions and ee (>99\%) was obtained using Tris, borax or phosphate buffer (Fig. 5a).

In case of $r a c$ - $p$-methylphenylalanine $(r a c-1 c)$, the optimal conversion $(\sim 50 \%)$ and enantiomeric excess $\left(e_{\mathrm{D}-}\right.$ 1c $>99 \%$ ) was obtained after $48 \mathrm{~h}$ reaction time using borax and sodium carbonate buffer. Although the reaction proceeded well also in $0.1 \mathrm{M} \mathrm{NH}_{3}\left(\mathrm{c}=46 \%\right.$, ee $\left.\mathrm{D}_{\mathrm{D}-1 \mathrm{c}}=96.4 \%\right)$, significantly lower conversion $(\mathrm{c}=26 \%)$ was obtained when using phosphate-buffer (Fig. 5b).

Probably, the reason for the incomplete reactions obtained using ammonium acetate or $0.1 \mathrm{M} \mathrm{NH}_{3}$ buffers (selected for their advantage of easy removal during the reaction work-up), is the occurrence of the reverse ammonia addition reaction, under the low ammonia content. While borax and Tris-buffer systems provide complete conversions for both model substrates, the slight differences in the optimal reaction medium suggest that for rigorous fine-tuning of the efficiency of resolution process, reaction medium tests should be performed for each individual substrate of interest.

The effect of biocatalysts: substrate ratio and substrate concentration. Further, the impact of the increased biocatalyst and substrate concentrations on the reactions of model substrates were tested. Firstly, whole-cell PcPAL biocatalysts with various cell densities $\left(\mathrm{OD}_{600}\right.$ of 1,2 , and 4$)$ were used at fixed $2 \mathrm{mM}$ substrate concentration. Generally, the increase of biocatalyst:substrate ratio $\left(2: 1\right.$ ratio of cell density $\left.\left(\mathrm{OD}_{600}\right): \mathrm{mM}\right)$ resulted shorter reaction times. Thus, when using cell densities of $\mathrm{OD}_{600} 4$, the optimal conversion of $\sim 50 \%$ was reached in $5 \mathrm{~h}$ in case 


\begin{tabular}{|c|c|c|c|c|}
\hline Substrate $(2 \mathrm{mM})$ & $\begin{array}{l}\text { Cell density }\left(\mathrm{OD}_{600}\right) / \text { biocatalyst: } \\
\text { substrate ratio }\left(\mathrm{OD}_{600}: \mathrm{mM}\right)\end{array}$ & c (\%) & $\mathrm{ee}_{\mathrm{D}-1}(\%)$ & $\mathrm{ee}_{\text {theorD-1 }}(\%)$ \\
\hline \multirow{3}{*}{$r a c-1 \mathrm{c}$} & $1 / 1: 2$ & $38.1^{\mathrm{a}}$ & 63.3 & 61.7 \\
\hline & $2 / 1: 1$ & $39.9^{\mathrm{a}}$ & 66.3 & 66.5 \\
\hline & $4 / 2: 1$ & $\sim 50^{\mathrm{a}}$ & 94.1 & $>99$ \\
\hline $\mathrm{F}_{3} \mathrm{C}$ & $1 / 1: 2$ & $27.3^{\mathrm{b}}$ & 37.5 & 37.5 \\
\hline & $2 / 1: 1$ & $45.6^{\mathrm{b}}$ & 88.8 & 84.0 \\
\hline$r a c-1 k$ & $4 / 2: 1$ & $\sim 50^{\mathrm{b}}$ & $>99$ & $>99$ \\
\hline
\end{tabular}

Table 2. The effect of cell densities upon conversion values in ammonia elimination reactions. ${ }^{\mathrm{a}}$ after $24 \mathrm{~h}$; bafter $5 \mathrm{~h}$; e $e_{\text {theor }}$ - theoretical enantiomeric excess, calculated by the formula: $\frac{c}{100-c} \times 100$; where $\mathrm{c}$ represents the experimentally determined conversion (\%); Reaction conditions: assays were performed in $1.5 \mathrm{~mL}$ polypropylene tubes at $30^{\circ} \mathrm{C}, 200 \mathrm{rpm}$, in $500 \mu \mathrm{L}$ reaction volume, using $2 \mathrm{mM}$ substrate concentration, different ratio of cell density $\left(\mathrm{OD}_{600}\right)$ /substrate concentration $(\mathrm{mM})$ and Tris buffer, $\mathrm{pH} 8.8$ as reaction medium.

a)
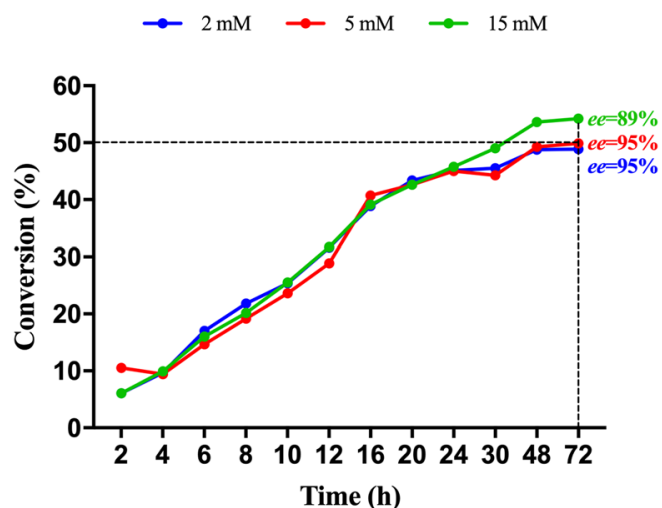

b)

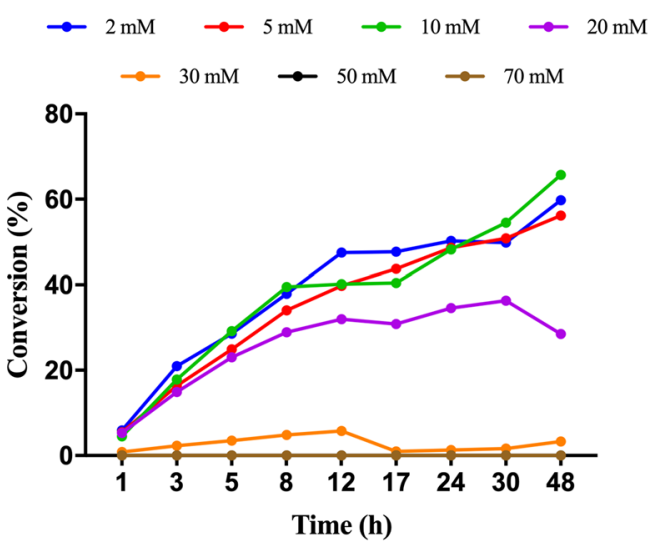

Figure 6. Time-conversion profiles for the ammonia elimination from (a) $p$ - $\mathrm{CH}_{3}$-amino acid $\mathrm{rac}$ - $1 \mathrm{c}$ and (b) $m$ $\mathrm{CF}_{3}$-amino acid rac-1k using I460V PcPAL, using different substrate concentrations.

of $\mathrm{rac}-\mathbf{1 c}$ and $24 \mathrm{~h}$ in case of rac-1k (Table 2), while lower cell densities of $\mathrm{OD}_{600} 1$ or 2 afforded similar conversions of $50 \%$ in longer reaction times $(30 \mathrm{~h}$ in case of $\mathrm{rac}-1 \mathbf{k}$ and $>48 \mathrm{~h}$ in case of $\mathrm{rac}-\mathbf{1 c}$ ).

The influence of substrate concentration on the resolution process of model substrates was also tested. When increasing the substrate concentration, using the optimal biocatalyst:substrate ratio of $2: 1\left(\mathrm{OD}_{600}: \mathrm{mM}\right)$, the corresponding increase of cell densities was also necessary, leading to the appearance of viscosity issues, hindering reaction monitoring. Therefore, evaluation of the effect of substrate concentrations, ranging between $2 \mathrm{mM}$ and the maximum solubility of model substrates rac-1k and rac-1c $(70 \mathrm{mM}$ and $15 \mathrm{mM}$, respectively), was performed with biocatalyst:substrate ratio of $1: 2\left(\mathrm{OD}_{600}: \mathrm{mM}\right)$.

In case of ammonia eliminations from $\mathrm{rac}$-1c, the conversion reached the optimal $50 \%$ with similar time progressions at each substrate concentrations tested (Fig. 6a). However, $e e_{\text {D-1c }}$ slightly decreased with the increase of substrate concentration, 95\% was obtained at 2 and $5 \mathrm{mM}$ concentration of rac-1c and conversions approximating the $50 \%$ optimal value, while at higher $15 \mathrm{mM}$ substrate concentration ee ${ }_{\mathrm{D}-1 \mathrm{c}}$ was $89 \%$ (Fig. $6 \mathrm{a}$ ). Notable, that the obtained ee values are slightly lower than the theoretical ees (Figs. S14-S16), supporting a not fully enantioselective resolution process, of which selectivity decreases by the increase of substrate concentration.

In the ammonia elimination of $\mathrm{rac}-\mathbf{1 k}$, using high substrate concentrations, low $\left(\mathrm{c}_{30 \mathrm{mM}}=6 \%\right)$ or no conversions (at substrate concentration $>30 \mathrm{mM}$ ) were obtained (Fig. 6b). The decrease of stationary conversion values upon increasing the concentration of rac-m-(trifluoromethyl)phenylalanine rac-1k (Fig. 6b), similarly to the ammonia addition onto 21 (Fig. S11), suggested the occurrence of substrate inhibition. This was confirmed by the kinetic measurements performed using purified PcPAL I460V (Fig. S23). Besides the significant decrease of conversions, at substrate concentrations exceeding $10 \mathrm{mM}$ of $r a c-1 \mathbf{k}$, the difference of the ee values registered for the unreacted $\mathrm{D}-\mathbf{1 k}$ and the theoretical ee values also increased, supporting the decrease of the enantioselectivity upon the increase of substrate concentration, similarly as in the case of model substrate rac-1c (Fig. 7).

Therefore, due to the influence of substrate concentration on the enantioselectivity of the resolution process, and the occurrence of substrate inhibition, the selection of the optimal substrate concentration based primarily on the final ee $\mathrm{D}_{\mathrm{D}-1}$ values, followed by the conversion values. Performing the ammonia eliminations of $\mathrm{rac}-1 \mathrm{c}$ and rac-1k under the optimal, relatively low, substrate concentrations (Table 3), high conversions, reaching the theoretical $50 \%$ of a kinetic resolution process, and high ee values ( $95 \%$ and $93 \%$, respectively) were obtained. 
a)

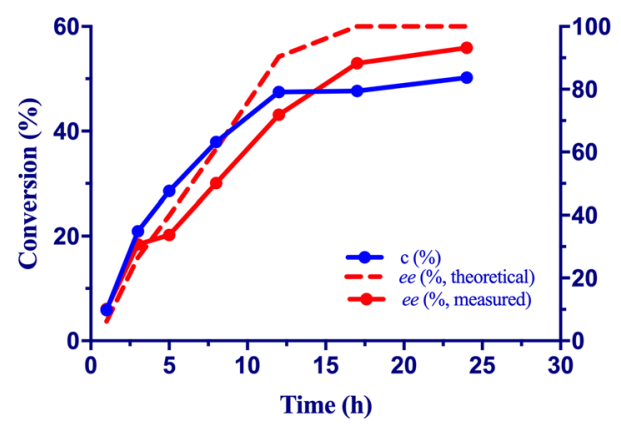

b)

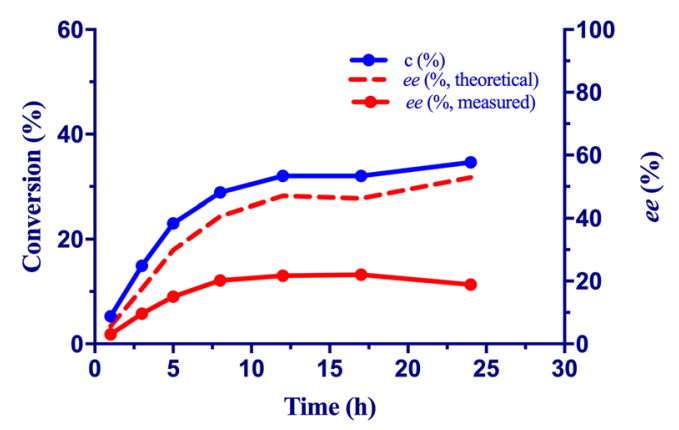

Figure 7. Conversion- and enantiomeric excess-time progression curves for the ammonia eliminations from $m-\mathrm{CF}_{3}$-amino acid rac-1k using I460V PcPAL and (a) $2 \mathrm{mM}$ and (b) $20 \mathrm{mM}$ substrate concentration.

\begin{tabular}{|l|l|l|l|l|l|l|}
\hline Substrate & Substituent & PcPAL & {$[\mathbf{S}](\mathbf{m M})$} & Time $(\mathbf{h})$ & $\mathbf{c}(\%)$ & $\mathbf{e e}_{\mathbf{D}}(\%)$ \\
\hline rac-1c & $p-\mathrm{CH}_{3}$ & $\mathrm{I} 460 \mathrm{~V}$ & 5 & 48 & $\sim 50$ & 95 \\
\hline rac-1k & $m-\mathrm{CF}_{3}$ & $\mathrm{I} 460 \mathrm{~V}$ & 2 & 23 & $\sim 50$ & 93 \\
\hline
\end{tabular}

Table 3. Conversion and $e e$ values of $\mathrm{D}-1 \mathrm{k}, \mathrm{c}$ obtained from the corresponding the ammonia elimination reactions performed under optimal conditions $s^{\mathrm{a}}$. ${ }^{\mathrm{a}}$ Reaction conditions: assays were performed in $1.5 \mathrm{~mL}$ polypropylene tubes at $30^{\circ} \mathrm{C}, 200 \mathrm{rpm}$ for $16 \mathrm{~h}$, in $500 \mu \mathrm{L}$ reaction volume, using the corresponding substrate concentration, ratio of cell density $\left(\mathrm{OD}_{600}\right) /$ substrate concentration $(\mathrm{mM})$ of 1.0 , and Borax buffer as reaction medium.

Preparative scale biotransformations. Accordingly, to obtain synthetically important Phe analogues in high optical purity, the optimized ammonia additions onto substrates $\mathbf{2 e}, \mathbf{2} \mathbf{i}$ and $\mathbf{2} \mathbf{k}$ and ammonia eliminations from $\mathrm{rac}-\mathbf{1 c}$, rac-1k were performed at preparative scale $(500 \mathrm{mg})$ (Fig. 8).

Using the optimal reaction conditions set-up by analytical scale biotransformations, the preparative scale biotransformation provided similarly high conversion and $e e$ values, affording the corresponding $\mathrm{D}$ - and $\mathrm{L}$ - amino acids in good conversions, isolated yields and optical purities (Table 4). The efficiency of ammonia eliminations, in terms of yields and enantiomeric excess values, are comparable with the kinetic resolutions performed with purified/commercial enzymes, such as the penicillin G acylase mediated enantioselective acylation for $\mathrm{D}$ - $p$-methylphenylalanine $\mathrm{D}-\mathbf{1} \mathrm{c}^{44}$, or the $\mathrm{L}$-AAO/catalase catalyzed kinetic resolution process yielding $\mathrm{D}$ - $m$ - $($ trifluoromethyl)phenylalanine $\mathrm{D}-\mathbf{1} \mathbf{k}^{45}$, a key chiral intermediate for $(R)-\mathrm{PFI}-2^{33}$. Definitely, in terms of conversions the kinetic resolution-type ammonia elimination of $r a c-1 c$ is surpassed by the asymmetric synthetic routes, such as the reductive amination of the corresponding keto-acid catalyzed by DAADH (D-amino acid dehydrogenase $)^{46}$, necessitating co-factor (NADPH) regeneration system or the L-amino acid deaminase and engineered aminotransferase coupled cascade, that uses $\mathrm{L}_{-}$or racemic amino acid $\mathbf{1 c}$ as starting material ${ }^{47}$. In this context the asymmetric synthesis-type ammonia additions, starting from inexpensive cinnamic acids, represent a more attractive synthetic route. Accordingly, in case of $\mathrm{L}-m$-(trifluoromethyl)phenylalanine $\mathrm{L}-\mathbf{1 k}$, intermediate for kinesin KIFC1 inhibitors ${ }^{32}$, the developed PAL-ammonia addition provides higher yield than the claimed enantioselective hydrolysis of corresponding carboxylic esters ${ }^{48}$. The yields for $\mathrm{L}-m$-methoxyphenylalanine $\mathrm{L}-1 \mathrm{e}$ are comparable with the yields of the recently reported, PbPAL mediated semi-preparative scale reaction (61\% yield, ee $>99 \%)^{40}$, but also with the aspartate aminotransferase catalyzed reductive amination ${ }^{49}$. The optically pure L- $p$-bromophenylalanine $\mathrm{L}-\mathbf{1} \mathbf{i}$, as versatile chiral intermediate ${ }^{12}$ was also obtained in high, $82 \%$ yield (Table 4 ), similarly as in case of using improved $A v \mathrm{PAL}$ variants ${ }^{12}$, but somewhat lower than the $94 \%$ reported yield when using the $31 \mathrm{E}$ variant of Rhodotorula graminis PAL (RgrPAL $)^{24}$.

\section{Methods}

Preparation of whole cell biocatalysts for enzymatic reactions - general procedure. The overnight preculture was prepared in Erlenmeyer flasks containing LB (Luria Bertani) medium supplemented with carbenicillin $(50 \mu \mathrm{g} / \mathrm{mL})$ and chloramphenicol $(30 \mu \mathrm{g} / \mathrm{mL})$ and inoculated with glycerol stocks of E. coli Rosetta (DE3) pLysS cells harbouring the pET19b vector carrying the $w t$ - or mutant pcpal gene ${ }^{50}$, followed by overnight incubation at $37^{\circ} \mathrm{C}$ and shaking at $200 \mathrm{rpm}$. The obtained preculture $(5 \mathrm{~mL})$ was further used to inoculate shake flasks (2l) containing $500 \mathrm{~mL} \mathrm{LB}$. Cultures were grown at $37^{\circ} \mathrm{C}, 200 \mathrm{rpm}$ until $\mathrm{OD}_{600}$ reached $0.6-0.8$, at which point protein production was induced via the addition of $0.1 \mathrm{mM}$ IPTG (final concentration), and the cell growth was maintained at $25^{\circ} \mathrm{C}$ for another $16 \mathrm{~h}$. Cell densities of $\mathrm{OD}_{600}$ were measured after for each mutant variant and wild-type PcPAL. The cells were harvested by centrifugation at $4000 \mathrm{rpm}(1751 \times \mathrm{g})$ and $4{ }^{\circ} \mathrm{C}$ for $20 \mathrm{~min}$ and washed with PBS buffer $(20 \mathrm{mM}$ phosphate, $150 \mathrm{mM} \mathrm{NaCl}, \mathrm{pH} 8.0)\left(4000 \mathrm{rpm}, 1751 \times \mathrm{g}, 4^{\circ} \mathrm{C}, 20 \mathrm{~min}\right)$ and stored at $-20^{\circ} \mathrm{C}$ in $1.5 \mathrm{ml}$ polypropylene tubes with $\mathrm{OD}_{600}$ of $\sim 2$ until further use. 
PcPAL I460V mediated preparative scale biotransformations:

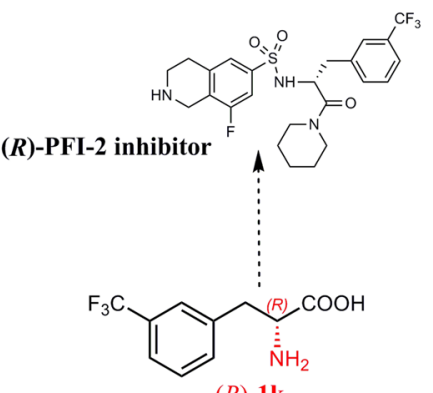

$(R)-1 \mathbf{k}$

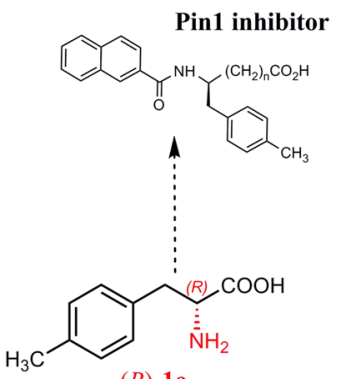

(R)-1c

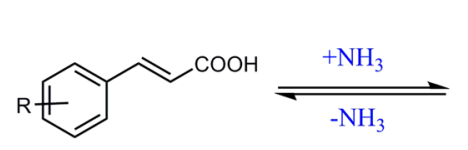

cinnamic acid analogue

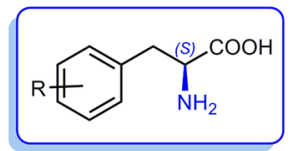

Product from ammonia addition

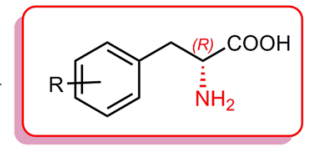

unreacted enantiomer from ammonia elimination
$(S)-\mathbf{1 k}$<smiles>CCCC1=C(C)SC(C(=O)NC(=O)C(Cc2ccc(-c3cccc(C(F)(F)F)c3)nc2)NC(=O)C2CCNC2)C1</smiles>

$(S)-1 \mathrm{e}$

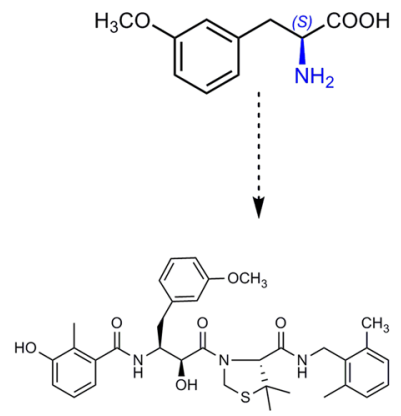

HIV protease inhibitor
(S)-1

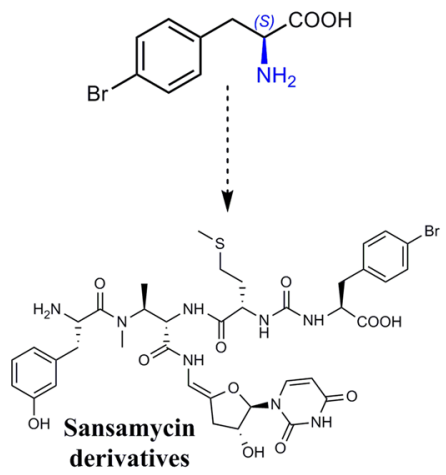

Figure 8. Preparative scale ammonia additions and ammonia eliminations providing access to synthetically valuable phenylalanine analogues.

\begin{tabular}{|c|c|c|c|c|c|}
\hline & Product & Reaction time (h) & $\mathrm{Y}^{\mathrm{b}}(\%)$ & ee $(\%)$ & {$[\alpha]_{D}^{27 \mathrm{c}}$} \\
\hline \multirow{3}{*}{ Ammonia addition } & $(S)$-2-amino-3-(3-methoxyphenyl)propanoic acid, $(S)$-1e & 42 & 59 & $>99$ & -66.4 \\
\hline & (S)-2-amino-3-(4-bromophenyl)propanoic acid, $(S)$-1i & 48 & 82 & $>99$ & -47.6 \\
\hline & (S)-2-amino-3-(3-(trifluoromethyl)phenyl)propanoic acid, $(S)$-1k & 48 & 52 & $>99$ & -35.2 \\
\hline \multirow{2}{*}{ Ammonia elimination ${ }^{a}$} & $(R)$-2-amino-3-( $p$-tolyl)propanoic acid, $(R)$-1c & 30 & 49 & 95 & +5.7 \\
\hline & (R)-2-amino-3-(3-(trifluoromethyl)phenyl)propanoic acid, $(R)-\mathbf{1 k}$ & 30 & 39 & 93 & +31.5 \\
\hline
\end{tabular}

Table 4. Preparative scale ammonia addition and ammonia elimination reactions. ${ }^{a}$ At $~ 50 \%$ conversion; ${ }^{b}$ The reaction yields were determined from the preparative scale reaction including product isolation, purification steps (for reaction conditions see ESI, chapter 4); ${ }^{\mathrm{c} T h e}$ measurements were performed: in $\mathrm{MeOH}$ with substrate concentration of $10 \mathrm{mg} / 1 \mathrm{~mL}$.

Biotransformation screenings for ammonia addition reactions - general procedure. The ammonia addition reactions were performed in duplicate using $1.5 \mathrm{ml}$ polypropylene tubes, containing the whole cell PcPAL-biocatalysts, prepared as described above. The bacterial pellet was resuspended to an $\mathrm{OD}_{600}$ of $\sim 2$, in $1 \mathrm{~mL}$ of ammonia source $\left(2,4,6 \mathrm{M} \mathrm{NH}_{4} \mathrm{OH} \mathrm{pH} 10\right.$ adjusted with $\left.\mathrm{CO}_{2}\right)$ and ammonium carbamate $(2,4,6 \mathrm{M}$ $\mathrm{NH}_{4}\left[\mathrm{H}_{2} \mathrm{NCO}_{2}\right], \mathrm{pH}$ 9.6-10 without adjustment). For the biotransformations, $2 \mathrm{mM}$ substrate (cinnamic acids 2a-l) concentrations were used, and the reaction mixtures were incubated at $30^{\circ} \mathrm{C}, 250 \mathrm{rpm}$ for specified reaction times. Conversions were monitored using reversed-phase high performance liquid chromatography (HPLC). Reaction samples were quenched by adding an equal volume of $\mathrm{MeOH}$, vortexed and centrifuged ( $13400 \mathrm{rpm}$, $12000 \times \mathrm{g}, 10 \mathrm{~min})$. The supernatant was filtered through a $0.22 \mu \mathrm{m}$ nylon membrane filter and analyzed by HPLC. 
Biotransformation screenings for ammonia elimination reactions- general procedure. The ammonia elimination reactions were performed in duplicate using $1.5 \mathrm{ml}$ polypropylene tubes, containing the whole cell PcPAL -biocatalysts, prepared as described above. The bacterial pellet was resuspended to an $\mathrm{OD}_{600}$ of $\sim$, in $1 \mathrm{~mL}$ of different buffers: Tris ( $20 \mathrm{mM}$ Tris. $\mathrm{HCl}, 120 \mathrm{mM} \mathrm{NaCl}, \mathrm{pH} 8.8,), \mathrm{NH}_{3}$-buffer $\left(0.1 \mathrm{M} \mathrm{NH}_{4} \mathrm{OH}\right.$, pH 9.5, adjusted with $\left.\mathrm{CO}_{2}\right)$, borax $\left(0.1 \mathrm{M} \mathrm{Na}_{2}\left[\mathrm{~B}_{4} \mathrm{O}_{5}(\mathrm{OH})_{4}\right]\right.$, $\left.\mathrm{pH} 9.5\right)$, ammonium acetate buffer $(0.1 \mathrm{M}$, pH 9.5, sodium carbonate $(0.1 \mathrm{M}, \mathrm{pH} 9.0)$ and phosphate-buffer $(0.1 \mathrm{M}$ phosphate, $\mathrm{pH} 8.8)$. For the biotransformations $2 \mathrm{mM}$ substrate (racemic amino acids rac-1a-1) concentrations were used, and the reaction mixtures were incubated at $30^{\circ} \mathrm{C}, 250 \mathrm{rpm}$ for different reaction times. Conversions were monitored using reversed-phase HPLC. Reaction samples were quenched by adding an equal volume of $\mathrm{MeOH}$, vortexed and centrifuged (13400 rpm, $12000 \times \mathrm{g}, 10 \mathrm{~min}$ ). The supernatant was filtered through a $0.22 \mu \mathrm{m}$ nylon membrane filter and analyzed by HPLC.

Preparative scale ammonia additions. In a $500 \mathrm{~mL}$ flask, E. coli Rosetta (DE3) pLysS cells harbouring the pET19b vector carrying the corresponding mutant pcpal gene were resuspended in $6 \mathrm{M} \mathrm{NH}_{4} \mathrm{OH}$-solution ( $\mathrm{pH} 9.8$ adjusted with $\mathrm{CO}_{2}$ ) to give a final $\mathrm{OD}_{600}$ of $\sim 10$ for $2 \mathrm{i}$ and $2 \mathrm{k}(13.26 \mathrm{~g}$ wet cells in $221 \mathrm{~mL}$ reaction volume and $13.92 \mathrm{~g}$ wet cells in $232 \mathrm{~mL}$ reaction volume, respectively) and a final $\mathrm{OD}_{600}$ of $\sim 30(16.92 \mathrm{~g}$ wet cells in $94 \mathrm{~mL}$ reaction volume) for $2 \mathrm{e} .0 .5 \mathrm{~g}$ cinnamic acid $2 \mathrm{e}, 2 \mathrm{i}, 2 \mathrm{k}(2.8,2.2,2.3 \mathrm{mmol}$, respectively) was added to the cell suspension in a final concentration of $30 \mathrm{mM}$ for $2 \mathrm{e}$ and $10 \mathrm{mM}$ for $2 \mathrm{i}, 2 \mathrm{k}$ and the reaction was incubated at $200 \mathrm{rpm}$, $30^{\circ} \mathrm{C}$ for 48 hours, monitoring the conversion values by reversed-phase HPLC. When stationary conversions were reached (Figs. 4a,b and S9) the reaction mixture was acidified to $\mathrm{pH} 1.5$ by dropwise addition of aqueous $\mathrm{H}_{2} \mathrm{SO}_{4}$ $(50 \% \mathrm{w} / \mathrm{v})$. The formed precipitate was removed by centrifugation at $10000 \mathrm{rpm}(10947 \times \mathrm{g}), 4^{\circ} \mathrm{C}$ for $20 \mathrm{~min}$., while the non-reacted cinnamic acid was removed by extraction with ethyl acetate $(3 \times 10 \mathrm{~mL})$. The amino acid found within the aqueous phase was purified by ion exchange chromatography using Dowex ${ }^{\circledR} 50 \mathrm{WX} 2$ resin, using $2 \mathrm{M} \mathrm{NH}_{4} \mathrm{OH}$ solution for elution. The fraction containing the final product was evaporated in a centrifugal evaporator affording the pure $\mathrm{L}$-amino acid $(0.29 \mathrm{~g}, 1.63 \mathrm{mmol}, 59 \%$ isolation yield for $(S)-1 \mathrm{e} ; 0.4 \mathrm{~g}, 1.76 \mathrm{mmol}$, $80 \%$ isolation yield for $(S)-1 \mathrm{i}$ and $0.26 \mathrm{~g}, 1.2 \mathrm{mmol}, 52 \%$ isolation yield for $(S)-1 \mathrm{k})$.

Preparative scale ammonia eliminations. In a $500 \mathrm{~mL}$ flask, E. coli Rosetta (DE3) pLysS cells harbouring the $\mathrm{pET} 19 \mathrm{~b}$ vector carrying the corresponding or mutant pcpal gene were resuspended in Borax buffer $(\mathrm{pH} 10$ unadjusted) to give a final $\mathrm{OD}_{600}$ of $\sim 7.5(12.51 \mathrm{~g}$ wet cell mass $/ 278 \mathrm{~mL}$ for $r a c-1 \mathrm{c}$ and $6.43 \mathrm{~g}$ wet cell mass $/ 143 \mathrm{~mL}$ rac-1k). Racemic phenylalanine analogue rac-1c or rac-1k $(0.25 \mathrm{~g}, 1.4 \mathrm{mmol}$, or $0.5 \mathrm{~g}, 2.1 \mathrm{mmol}$, respectively) was added to the cell suspension in a final concentration of 5 or $15 \mathrm{mM}$, respectively and the reactions were incubated at $200 \mathrm{rpm}, 30^{\circ} \mathrm{C}$ for 48 hours, monitoring the conversion values by reversed-phase HPLC (Figs. S11, S12). When stationary conversions were reached, the reaction mixtures were purified using the method described above for the preparative scale ammonia addition, providing the $\mathrm{D}$ - amino acids $(0.245 \mathrm{~g}, 1.34 \mathrm{mmol} 49 \%$ isolation yield for $(R)-1 \mathrm{c}$ and $0.19 \mathrm{~g}, 0.82 \mathrm{mmol}$ and $39 \%$ isolation yield for $(R)-1 \mathrm{k})$.

\section{Conclusions}

Within this study, we developed highly efficient biocatalytic procedures for the synthesis of valuable enantiopure L- and D- Phe, using as whole-cell biocatalyst recombinant E. coli cells harbouring the plasmid of PcPAL mutants (L256V, L134A, I460V), specifically tailored towards the targeted ring-substituted cinnamic acid and phenylalanine substrates.

In case of ammonia addition reactions, regarding to substrate solubility and reaction time, the optimal reaction medium was found to be $6 \mathrm{M} \mathrm{NH}_{4} \mathrm{OH}$, while in several cases the substrate concentration significantly affected the final conversions. Substrates bearing ortho-substituents or para-electron donating substituents were transformed with high conversions (66-91\%) even at high substrate concentrations $(30-70 \mathrm{mM})$, while in case of substrates with meta- or electron withdrawing para-substituents high substrate concentrations $(>2-10 \mathrm{mM})$ significantly lowered the final conversion values, substrate inhibition occurring in several cases.

In case of ammonia elimination reactions, the reaction medium affected slightly, but differently the kinetic resolution of the model substrates, suggesting specific conditions for each substrate of interest. Using an optimal biocatalyst:substrate ratio, inhibitory effect occurred at high substrate concentration $(>2-5 \mathrm{mM})$, while the enantioselectivity of the resolution process also decreased, forcing the use of relatively low substrate concentrations.

Finally, the preparative scale ammonia addition reactions of $m$-methoxy-cinnamic acid $2 \mathbf{e}, p$-bromo-cinnamic acid $2 \mathbf{i}, m$-(trifluoromethyl)cinnamic acid $2 \mathbf{k}$ and ammonia elimination reactions of rac- $p$-methylphenylalanine rac-1c, rac-m-(trifluoromethyl)phenylalanine rac-1k were performed under their specific optimal conditions, producing in high yields and ees the corresponding, highly valuable $\mathrm{L}-$ and D- phenylalanines.

Received: 9 September 2019; Accepted: 12 December 2019;

Published online: 27 December 2019

\section{References}

1. Wakiec, R. et al. Enhanced susceptibility to antifungal oligopeptides in yeast strains overexpressing ABC multidrug efflux pumps. Antimicrob. Agents Chemother. 52, 4057-4063 (2008).

2. Slaninová, J., Maletínská, L., Vondrášek, J. \& Procházka, Z. Magnesium and biological activity of oxytocin analogues modified on aromatic ring of amino acid in position 2. J. Peptide Sci. 7, 413-424 (2001).

3. Parmeggiani, F., Weise, N. J., Ahmed, S. T. \& Turner, N. J. Synthetic and therapeutic applications of ammonia-lyases and aminomutases. Chem. Rev. 118, 73-118 (2018).

4. Heberling, M. M., Wu, B., Bartsch, S. \& Janssen, D. B. Priming ammonia lyases and aminomutases for industrial and therapeutic applications. Curr. Opin. Chem. Biol. 17, 250-260 (2013).

5. Liu, W. (Great Lakes Chemical Co.), US Pat 5,981,239, 1999. [Chem. Abstr. 131, 321632 (1999). 
6. Turner, $\mathrm{N}$. Ammonia lyases and aminomutases as biocatalysts for the synthesis of $\alpha$-amino and $\beta$-amino acids. Curr. Opin. Chem. Biol. 15, 234-240 (2011).

7. Dreßena, A., Hilberatha, T., Mackfeld, U., Rudatb, J. \& Pohla, M. Phenylalanine ammonia lyase from Arabidopsis thaliana (AtPAL2): A potent MIO-enzyme for the synthesis of non-canonical aromatic alpha-amino acids. Part II: Application in different reactor concepts for the production of (S)-2-chloro-phenylalanine. J. Biotechnol. 258, 158-166 (2017).

8. Nagy, E. Z. A. et al. Mapping the hydrophobic substrate binding site of phenylalanine ammonia lyase from Petroselinum crispum. ACS Catal. 9, 8825-8834 (2019).

9. Filip, A. et al. Tailored mutants of phenylalanine ammonia-lyase from Petroselinum crispum for the synthesis of bulky l-and d-arylalanines. Chem. Med. Chem. 10, 2627-2633 (2018).

10. Lovelock, S. L. \& Turner, N. J. Bacterial Anabaena variabilis phenylalanine ammonia lyase: A biocatalyst with broad substrate specificity. Bioorg. Med. Chem. 22, 5555-5557 (2014).

11. Weise, N. J. et al. Intensified biocatalytic production of enantiomerically pure halophenylalanines from acrylic acids using ammonium carbamate as the ammonia source. Catal. Sci. Technol. 6, 4086-4089 (2016).

12. Ahmed, S. T., Parmeggiani, F., Weise, N. J., Flitsch, S. L. \& Turner, N. J. Chemoenzymatic Synthesis of optically pure L- and D-biarylalanines through biocatalytic asymmetric amination and palladium-catalyzed arylation. ACS Catal. 5, 5410-5413 (2015).

13. Jia, S. R., Cui, J. D., Yan, L. \& Sun, A. Y. Production of L-phenylalanine from trans-cinnamic acids by high-level expression of phenylalanine ammonia lyase gene from Rhodosporidium toruloides in Escherichia coli. Biochem. Eng. J. 42, 193-197 (2008).

14. Cui, J. D., Qiu, J. Q., Fan, X. W., Jia, S. R. \& Tan, Z. L. Biotechnological production and applications of microbial phenylalanine ammonia lyase: a recent review. Crit. Rev. Biotechnol. 34, 258-268 (2014).

15. de Lange, B. et al. Asymmetric synthesis of $(S)$-2-indolinecarboxylic acid by combining biocatalysis and homogeneous catalysis. ChemCatChem. 3, 289-292 (2011).

16. Gloge, A., Zoń, J., Kővári., Á., Poppe, L. \& Rétey, J. Phenylalanine ammonia-lyase: The use of its broad substrate specificity for mechanistic investigations and biocatalysis - Synthesis of L-arylalanines. Chem. Eur. J. 6, 3386-3390 (2000).

17. Paizs, C., Katona, A. \& Rétey, J. The interaction of heteroarylacrylates and alanines with phenylalanine ammonia-lyase from parsley. Chem. Eur. J. 12, 2739-2744 (2006).

18. Paizs, C. et al. 2-amino-3-(5-phenylfuran-2-yl)propionic acids and 5-phenylfuran-2-ylacrylic acids are novel substrates of phenylalanine ammonia-lyase. Heterocycles. 82, 1217-1228 (2010).

19. Bartha-Vári, J. H. et al. Immobilization of phenylalanine ammonia lyase on single-walled carbon nanotubes for stereoselective biotransformations in batch and continuous-flow modes. ChemCatChem. 7, 1122-1128 (2015).

20. Bartha-Vári, J. H. et al. Aminated single-walled carbon nanotubes as carrier for covalent immobilization of phenylalanine ammonialyase. Period. Polytech. Chem. Eng. 61, 59-66 (2017).

21. Baedeker, M. \& Schulz, G. E. Overexpression of a designed $2.2 \mathrm{~kb}$ gene of eukaryotic phenylalanine ammonia-lyase in Escherichia coli. FEBS Lett. 457, 57-60 (1999).

22. Bencze, L. C. et al. Expanding the substrate scope of phenylalanine ammonia-lyase from Petroselinum crispum towards styrylalanines. Org. Biomol. Chem. 15, 3717-3727 (2017).

23. Bartsch, S. \& Bornscheuer, U. T. Mutational analysis of phenylalanine ammonia lyase to improve reactions rates for various substrates. Protein Eng. Des. Sel. 23, 929-933 (2010).

24. Rowles, I. et al. Engineering of phenylalanine ammonia lyase from Rhodotorula graminis for the enhanced synthesis of unnatural 1-amino acids. Tetrahedron 72, 7343-7247 (2016).

25. Ahmed, S. T., Parmeggiani, F., Weise, N. J., Flitsch, S. L. \& Turner, N. J. Engineered ammonia lyases for the production of challenging electron-rich l-phenylalanines. ACS Catal. 8, 3129-3132 (2018).

26. Wu, B., Szymanski, W., Heberling, M. M., Feringa, B. L. \& Janssen, D. B. Aminomutases: mechanistic diversity, biotechnological applications and future perspectives. Trends. Biotech. 29, 352-362 (2011)

27. Wu, B. et al. Mechanism-inspired engineering of phenylalanine aminomutase for enhanced $\beta$-regioselective asymmetric amination of cinnamates. Angew. Chem. 124, 497-501 (2012).

28. Bartsch, S. et al. Redesign of a phenylalanine aminomutase into a phenylalanine ammonia lyase. Chem CatChem 5, 1979-1802 (2013).

29. Wu, B. et al. Mechanism-inspired engineering of phenylalanine aminomutase for enhanced $\beta$-regioselective asymmetric amination of cinnamates. Angew. Chem. Int. Ed. 51, 482-486 (2012).

30. Wu, B. et al. Enzymatic synthesis of enantiopure alpha- and beta-amino acids by phenylalanine aminomutase-catalysed amination of cinnamic acid derivatives. ChemBioChem 10, 338-344 (2009).

31. Szymanski, W. et al. Phenylalanine aminomutase-catalyzed addition of ammonia to substituted cinnamic acids: a route to enantiopure $\alpha$ - and $\beta$-amino acids. J. Org. Chem. 74, 9152-9157 (2009).

32. Yang, B. et al. Discovery of potent KIFC1 inhibitors using a method of integrated high-throughput synthesis and screening. J. Med. Chem. 57, 9958-9970 (2014).

33. Lenstra, D. C. et al. Structure-activity relationship studies on (R)-PFI-2 analogs as inhibitors of histone lysine methyltransferase SETD7. Chem. Med. Chem. 13, 1405-1413 (2018).

34. Dong, L. et al. Structure-based design of novel human Pin1 inhibitors (II). Bioorg. Med. Chem. Lett. 20, 2210-2214 (2010).

35. Hwang, T. L. et al. Design and synthesis of tryptophan containing dipeptide derivatives as formyl peptide receptor 1 antagonist. Org. Biomol. Chem. 11, 3742-3755 (2013).

36. Arava, V. R. et al. Asymmetric synthesis of unnatural amino acids and Tamsulosin chiral intermediate. Synth. Commun. 43, 2892-2897 (2013).

37. Mimoto, T. et al. Structure-activity and structure-metabolism relationships of HIV protease inhibitors containing the 3-hydroxy2-methylbenzoylallophenylnorstatine structure. Bioorg. Med. Chem. 12, 281-293 (2004).

38. Dreßena, A. et al. Phenylalanine ammonia lyase from Arabidopsis thaliana (AtPAL2): A potent MIO-enzyme for the synthesis of non-canonical aromatic alpha-amino acids Part I: Comparative characterization to the enzymes from Petroselinum crispum (PcPAL1) and Rhodosporidium toruloides (RtPAL). J. Biotechnol. 258, 148-157 (2017).

39. Parmeggiani, F., Lovelock, S. L., Weise, N. J., Ahmed, S. T. \& Turner, N. J. Synthesis of d- and l-phenylalanine derivatives by phenylalanine ammonia lyases: A multienzymatic cascade process. Angew. Chem. Int. Ed. 54, 4608-4611 (2015).

40. Weise, N. J. et al. Zymophore identification enables the discovery of novel phenylalanine ammonia lyase enzymes. Sci. Rep. 7, 13691 (2017).

41. Hyun, M. W., Yun, Y. H., Kim, J. Y. \& Kim, S. H. Fungal and plant phenylalanine ammonia-lyase. Mycobiology 39, 257-265 (2011).

42. Michelle, C. M. et al. Discovery of two cyanobacterial phenylalanine ammonia lyases: kinetic and structural characterization. Biochemistry. 46, 1004-1012 (2007).

43. Fan, Z. et al. Modulating the $\mathrm{pH}$ activity profiles of phenylalanine ammonia lyase from Anabaena variabilis by modification of center-near surface residues. Appl. Biochem. Biotechnol. 183, 699-711 (2017).

44. Gong, X., Su, E., Wang, P. \& Wei, D. Alcaligenes faecalis penicillin G acylase-catalyzed enantioselective acylation of dl-phenylalanine and derivatives in aqueous medium. Tetrahedron Lett. 52, 5398-5402 (2011).

45. Pirrung, M. C. \& Krishnamurthy, N. Preparation of $(R)$-phenylalanine analogues by enantioselective destruction using l-amino acid oxidase. J. Org. Chem. 58, 967-958 (1993). 
46. Parmeggiani, F. et al. Single-biocatalyst synthesis of enantiopure d-arylalanines exploiting an engineered d-amino acid dehydrogenase. Adv. Synth. Catal. 358, 3298-3306 (2016).

47. Walton, C. J. W. et al. Engineered aminotransferase for the production of D-phenylalanine derivatives using biocatalytic cascades. ChemCatChem 10, 470-474 (2018).

48. Hans Ullrich, H., Merten, S. \& Reinhold, K. (From Ger. Offen.) DE 3733506 A1 19890413 (1989).

49. Yu, J. et al. Chemoenzymatic synthesis of 1-3,4-dimethoxyphenyl-alanine and its analogues using aspartate aminotransferase as a key catalyst. Catal. Commun. 120, 28-32 (2019).

50. Dima, N. A. et al. Expression and purification of recombinant phenylalanine ammonia-lyase from Petroselinum crispum. Stud. Univ. Babes-Bolyai Ser. Chem. 61, 21-34 (2016).

\section{Acknowledgements}

This work was financed by the Swiss National Science Foundation (SNSF) - project PROMYS, grant nr. IZ11Z0_166543. C.P. and M.I.T. thanks for the National Authority for Scientific Research and Innovation (ANCSI) and European Regional Development Fund, Competitiveness Operational Program 2014-2020 (POC), Priority axis 1, Action 1.1 (project NEMSyB, ID P37_273, Cod MySMIS 103413) for funding. L. C. thanks ELTE Márton Áron Special College for support.

\section{Author contributions}

L.C.B. conceived the project and designed the experiments. E.Z.A.N. and S.D.T. was responsible for the optimization of the biotransformations (under the supervision of L.C.B.). D.M.B was responsible for the preparation of whole-cell PcPAL-biocatalysts and purification of I460V PcPAL. L.C. and S.D.T. performed the substrate inhibition studies, while B.N. contributed with substrate synthesis. M.I.T., C.P. and L.C.B supervised all data and wrote the paper. All authors reviewed the manuscript.

\section{Competing interests}

The authors declare no competing interests.

\section{Additional information}

Supplementary information is available for this paper at https://doi.org/10.1038/s41598-019-56554-0.

Correspondence and requests for materials should be addressed to L.C.B.

Reprints and permissions information is available at www.nature.com/reprints.

Publisher's note Springer Nature remains neutral with regard to jurisdictional claims in published maps and institutional affiliations.

(c) (i) Open Access This article is licensed under a Creative Commons Attribution 4.0 International License, which permits use, sharing, adaptation, distribution and reproduction in any medium or format, as long as you give appropriate credit to the original author(s) and the source, provide a link to the Creative Commons license, and indicate if changes were made. The images or other third party material in this article are included in the article's Creative Commons license, unless indicated otherwise in a credit line to the material. If material is not included in the article's Creative Commons license and your intended use is not permitted by statutory regulation or exceeds the permitted use, you will need to obtain permission directly from the copyright holder. To view a copy of this license, visit http://creativecommons.org/licenses/by/4.0/.

(c) The Author(s) 2019 